\title{
Perception of Justice in Performance Appraisal; A Comparative Study of Public And Private Institutions of Pakistan
}

\author{
Dr. Muhammad Shaukat Malik \\ Director of Institute of Banking \& Finance, \\ Bahauddin Zakariya University. Pakistan
}

Seemab Zahra Chishti

Institute of Banking and Finance,

Bahauddin Zakariya University. Pakistan

Received: Aug. 27, 2018 Accepted: Sep. 25, 2018 Online published: Oct. 28, 2018

doi:10.5296/ijhrs.v8i4.13830

URL: https://doi.org/10.5296/ijhrs.v8i4.13830

\begin{abstract}
Performance Appraisal is very crucial process for the success of any organization. The aim of this study is to assess the employees' perception of justice related to the Performance Appraisal System and its impact on the satisfaction level with the help of supervisor role as moderator. Non probability sampling technique is used with survey questionnaire to collect the data. All results are based on quantitative techniques. The research investigates the information about employee's perception of performance appraisal and its effect on their level of satisfaction. The 200 responses were obtained from different institution of public and private sector of Pakistan, those institutions are from Banking and Airline Sector. Study do not support the supervisor role as moderator. On the other hand comparison of Public and Private Institutions shows minimal difference among perception of their employees and also there is very less difference existing among performance appraisal practices of both sectors of Pakistan.
\end{abstract}

\section{Introduction}

All over the present business setting there is quick transformation, with globalization, liberalized market places, and rivalry among companies is also high. Businesses require to continually change to preserve competitive advantage in the market. For this purpose, 
companies need to both develop and sustain strong ranks of performance. Progressively, an organization's achievement be contingent on their employees and their skills. Worthy workers are a chief asset to a company and are also provide the way towards competitive advantage.

In contemporary competitive \& modest business world, it is assumed that companies can contend with their competitors through something innovative. Moreover, progressing and updating the HR activities is of the best way to get new ideas and innovation. Therefore, with effective performance appraisal procedure, managers are able to retain most beneficial employees for the organization and make their scheme more efficient.

Performance appraisal has progressively become portion of a developed strategic attitude to incorporating HR actions and business guidelines and can now be perceived as a general approach covering a range of different methods. Through these methods companies try to judge workers and improve their skills, capability, increase their performance and allocate compensation and rewards. Tatum, B.C., Bradberry, T., Eberlin, R. and Kottraba, C. (2002), claimed that, the number of companies implementing an effective system of performance appraisal is limited. Despite of its' contradictory practices, performance appraisal is commonly used to measure and predict employee performance in all types of business either large or small. Performance appraisal is defined as "a regular assessment of the productivity of a person/employee's measured against certain expectations or pre-set standards". Overall, Performance appraisal is an organized technique of assessing an employee performance and his ability for growth.

Organizational performance and its subsequent efficacy and efficiency can only be attained when workers are constantly appraised and assessed. The failure of companies to implement an effective performance appraisal policy has stuck them from attaining competitive position in the market. So, the Performance appraisal is an important human resource management task that is observed as a division of performance management. Robins SP (2005) discourses that "performance appraisal is a technique of assessing the behavior of workers in the work place, usually containing both the quantitative \& qualitative sides of work performance". Dessler (2008) outlooks performance appraisal as any "process that involves setting work criterions, evaluating employee's real performance comparative to those criterions, and delivering feedback to the workers with the goal of encouraging them to remove performance shortages or to remain to achieve above par".

There are several perceptions attached with the system of performance appraisal, but the most important is the equality and justice from the management of the organization. Justice has critical importance in every procedure of business. The satisfaction level and good performance of employees all are based on Justice in Human resource procedure of any organization and the

However, the process remains to generate unhappiness among workers and can usually be perceived as unfair and unsuccessful. Boachie-Mensah, F.O. \& Seidu, P. (2012) specified that perceived justice of the assessment scheme has appeared as the most significant problem to be confronted by managers. The study of Nair \& Salleh (2015) exposes that if ratee don't perceive, agree, upkeep and observe a complete performance appraisal as fair, it will 
absolutely not achieve its aims and consequently the whole procedure of performance appraisal will fail. Workers that perceive this procedure is just will intentionally deal something positive in reaction to the business like high commitment and also they are also highly satisfied.

The scope of research is enhanced by the study of (Palaiologos, Papazekos \& Panayotopoulou, 2011) and they explore if dissatisfaction articulated with the Performance Appraisal System, it could be related two facets of Organization justice. These two facets of Organizational Justice were explored; Procedural justice and Distributive Justice. Procedural Justice was further divided into 2 major areas for research. The 1st area was the perceived rationality of the Performance Appraisal System itself, and defined as a "system" of justice. The 2nd was the perceived fairness of the method in which the Performance Appraisal process is passed out, and it is defined as the "process" of justice. After it the other justice aspect which was explored is distributive justice and it is based on the results of performance appraisal system. In Pakistan more hurdles are identified in public sector than private sector, there is a clear gap in both systems. Organizations made many rules but don't follow those rules it is a big problem that what should be implemented and what is implemented are different from each other. To clarify this gap and to analyze the general practice of the organizations and to investigate the outcomes of perception of employees, this research provide useful results.

In Pakistan, there is difference existed among private and public sector (Ikramullah, M., B. Shah, et al. 2012) and this study is also conducted to compare appraisal system in both sectors and to see the reality behind their operations. For this purpose, this study selected major banks and airlines of public and private sector of Pakistan. The reason behind this selection is that the most efficient and competitive Government sector organizations comes under the area of banks and airlines. Other organizations are not at the level that can compete with private sector organizations or some are non-profit organizations. The information gathered from the target respondents below the titles of every method of analysis used in the study. They were interpreted, deliberated and analyzed by the investigator. All statistical analysis was done on SPSS software version 22. Therefore, overall results of all statistical techniques demonstrate the perception of employees about performance appraisal system and observe the role of supervisor in the whole process in Private and Public institutions of Pakistan.

\section{Literature Review}

\subsection{Performance Appraisal Process: Definitions, Procedures \& Opinions}

Over the years, diverse literatures have discoursed the descriptions, definition, procedures, and opinions about the term of "performance appraisal". In the current study, the term performance appraisal is well-defined as the orderly assessment of the performance of workers and the consideration of the capabilities of an individual for advance progress and growth. 
Table 2.1. Performance Appraisal Description

\begin{tabular}{l|l|l}
\hline Author & Year & Description of Performance Appraisal \\
\hline $\begin{array}{l}\text { Gomez-Mejia, } \\
\text { Balkin, \& Cardy }\end{array}$ & $\mathbf{2 0 1 0}$ & $\begin{array}{l}\text { Performance appraisal (PA) practices are the basics of } \\
\text { performance management method. }\end{array}$ \\
\hline Desler & $\mathbf{2 0 0 8}$ & $\begin{array}{l}\text { performance appraisal as any technique that includes situation } \\
\text { of work criterions, evaluating the workers real performance } \\
\text { comparative to specified pre-set standards, \&delivering } \\
\text { feedback to workers with the goal of encouraging them to } \\
\text { remove performance shortages or to last to achieve above } \\
\text { normal ranking. }\end{array}$ \\
\hline $\begin{array}{l}\text { Abu-Doleh and } \\
\text { Weir }\end{array}$ & $\mathbf{2 0 0 7}$ & $\begin{array}{l}\text { performance appraisal or assessment is an orderly and sporadic } \\
\text { procedure that measures an employee's work performance and } \\
\text { efficiency in association to some pre-established standards and } \\
\text { organizational goals. }\end{array}$ \\
\hline Vance & $\mathbf{2 0 0 6}$ & $\begin{array}{l}\text { process of performance appraisal is actually planned to } \\
\text { involve, support, and unite persons and group energy to } \\
\text { constantly develop and attain organizational mission } \\
\text { achievement. }\end{array}$ \\
\hline $\begin{array}{l}\text { Jackson } \\
\text { Schuler }\end{array}$ & $\mathbf{2 0 0 3}$ & $\begin{array}{l}\text { assessing performance founded on the opinions and views of } \\
\text { juniors, peers, administrator, other managers and sometimes } \\
\text { employees themselves }\end{array}$ \\
\hline Mondy et al. & $\mathbf{2 0 0 2}$ & $\begin{array}{l}\text { performance appraisal as an arrangement of evaluation and } \\
\text { estimation of a target person or group performance and the } \\
\text { procedure of assessing performance inside the organizations. }\end{array}$ \\
\hline Fletcher & $\mathbf{2 0 0 1}$ & $\begin{array}{l}\text { the process of performance appraisal as the arrangements } \\
\text { whereby a company allocate some markl to specify the } \\
\text { performance level of specific individuals or teams. } \\
\text { performance appraisal in broader term as actions through } \\
\text { which companies pursue to evaluate workers and improve } \\
\text { their ability, improve performance and on the basis of that } \\
\text { evaluation allocate rewards to the employees. }\end{array}$ \\
\hline DeNisi & $\mathbf{2 0 0 0}$ &
\end{tabular}

Wilson \& Western (2000) intended that an operative performance appraisal needs significant time and energy of supervisors and collecting the information and getting feedback from employees. Some supervisors don't take their duty seriously or don't have the abilities desired to do a worthy occupation of appraising performance and delivering feedback. Such as, some workers don't peacefully receive the feedback, and sometimes they are irritated with an unproductive performance appraisal scheme and end-up trusting that the method is discriminating and unfair.

\subsection{Perception of Justice in Appraisal Procedure}

In the previous decade there has been much consideration given to perception of justice in organizational activities as a practical construct and a chief research area in Industrial Psychology. Perception of justice refers to the just and fair treatment of persons in an organization (Greenberg, 1998). Workers Perception of justice about performance appraisal have been revealed to be related to the satisfaction of workers with the performance appraisal method and also with the organizational policies. Justice in performance appraisal has been deliberated by several scholars over time. In the research of Ahmed, I., Ramzan, M., 
Mohammad, S. K., \& Islam, T. (2011), it was specified that the most vital performance appraisal problem confronted by companies is the perceived justice involved in the process of performance evaluation and the performance assessment scheme. Their results recommended that most of the workers perceive their system of performance appraisal not fair and not accurate. Cohen-Charach et al., (2001) propose that the appraisal procedure can become a foundation of great dissatisfaction when workers consider the method is biased, dogmatic or unrelated. A main concern for organizational front-runners is that the overall procedure of performance appraisal and the evaluation procedure of performance are usually perceived as together erroneous and partial.

\subsection{Types of Justice}

According to Cole \& Flint, (2004) the performance appraisal procedure is a good illustration of what can go incorrect in the organization. If Justice and fairness is not reflected and supervisors fail to recognize their personal duty for the consequences. Without a rigorous and fair performance appraisal method, it is probable that the employees of that organization are not satisfied and as a result, they are less committed to the organization. The Researchers Werner and Bolino, (1997) have introduced four main types of Justice 1) Procedural Justice, 2) Distributive Justice 3) Administrative Justice and 4) interactional justice. Here the focus of the research is based on two main types of justice, one is the procedural justice (that is based on fairness during the whole process) and the second is Distributive Justice (that how organizations allocate decisions based on justice and fairness).

Distributive justice that mentions to the perceived fairness concerning the authentic or estimated (expected) results, is also significant in any performance appraisal procedure. Assessments that fall short on any of these dimensions of perceived justice will be supposed as discriminating or unjust, and should be evaded for numerous reasons, with maybe the legal significances being the most convincing. (Richard J. Eberlin \& B. Charles Tatum, 2008)

Perception of justice is a useful element for the purpose to inspect the results and procedures of performance appraisal. It is essential to the vital psychological agreement and to employee satisfaction and flexible effort. It is also supportive for both practice \& theory if new expansions in performance appraisal can be inspected through this point of view.

In the past, fairness or justice related to the appraisal was observed as either the perceived justice or fairness of the rating used in performance appraisal or the perceived fairness of the about the appraisal as a whole. However, in contemporary world, researchers in performance appraisal have carried several other concepts in which the above both concepts of procedural justice and distributive justice are leading and researchers have used these measures to evaluate and defend the problem of fairness. So, appraisal justice has been taken in four diverse meanings:

i. Justice with ratings used for measuring performance,

ii. Justice with the overall appraisal system,

iii. Procedural justice 
iv. Distributive justice.

\subsection{Employees Satisfaction}

Satisfaction of performance appraisal is a sign of the mark to that workers are satisfied, works as an evidence of the precision and fair assessments of performance, \& the sensation that they will develop their working associations with their managers or supervisors. In this respect, McCarthy and Gupta, V., \& Kumar, S. (2012) theorized satisfaction with the help of4 item scale of measurement: whether the company must improve or alter the appraisal scheme, or there are fewer work difficulties getting up as an outcome of the performance appraisal method, or workers are satisfied with the technique the company accompanied the appraisal process, or having the process of performance appraisals is not more than a waste of time.

Analysts McCarthy and Garavan, (2001) claim that performance feedback results in increasing the job satisfaction, enthusiasm, several decision-making and job growth models contain a feedback loop highlighting that persons learn on the basis of getting feedback about their performance. Therefore, performance feedback have a significant role in several organizational activities like as profession development, inspiration, job satisfaction, \& management of performance. It is also evidence from pas research that if perceived satisfaction related to ratings is present, it also lead to procedural justice. Furthermore, satisfaction with the rater and response are an association facet of Performance Appraisal, therefore more related to procedural justice.

According to Ikemefuna, C. O., \& Chidi, C. O. (2012) the second, and most important is satisfaction with rater/supervisor. Here, the foundational role that managers have in order to encourage positive results becomes separate, as they are generally the workers' appraisers and deliver feedback for their performance. Conferring to a research, the most significant Performance Appraisal item is the worker and supervisor relationship. There is another element of satisfaction that is satisfaction related to feedback of appraisal system. Feedback is very necessary and critical phenomenon because of its potential impact on people's reaction to ratings.

\subsection{Supervisor Role}

Jawahar, I. (2007) believes that "supervision" is a kind of interactive collaboration in which communications are delivered over a specific method and individuals are made to trust that the outcomes of an act could be enhanced as long as they track a recommendation or expectancy. Cook, J., \& Crossman, A. (2004) considered worker perceptions of the justice and precision of a performance appraisal procedure based on the behavior of supervisor. The study of Naji, A., Ben Mansour, J., \& Leclerc, A. (2015) establish that regularity of assessment, identification of objectives to remove flaws, and managerial information assistant's level of performance and work obligations were considerably connected to views of justice and correctness of performance evaluation.

Supervisor has a great role in making the appraisal process fair or unfair. Rowland \& Hall, (2012) identify 7 procedural elements significant for supervisors. These are: 
(1) Providing sufficient attention to employees' viewpoints;

(2) Overturning biasness;

(3) Applying decision-making standards steadily across employees;

(4) Given that timely feedback to workers after the decision;

(5) avoid negative use of power and authority;

(6) Being honest in communication; and

(7) Handling employees with politeness and courtesy.

Some of these elements are used in this analysis to check respondent's perceptions of appraisal. According to the Lira (2014) feeling injustice in the organization may have adverse mental, emotional, and interactive costs for workers.

\section{Research Model}

The research framework of this study taken the perceived justice as independent variable and employee satisfaction about performance appraisal as dependent variable while supervisor role as mediator. In detail we divided the perceived justice into two main dimension procedural justice and distributive justice, while the appraisal system and appraisal outcomes are the parts of performance appraisal process. On the other hand, employees' satisfaction can be measured through employee perception about the whole process, while supervisor role is based on his fair behavior or unfair behavior. This model is helpful in understanding the whole relationship of variables. Hypothesis are built on the basis of the relationship among variables.

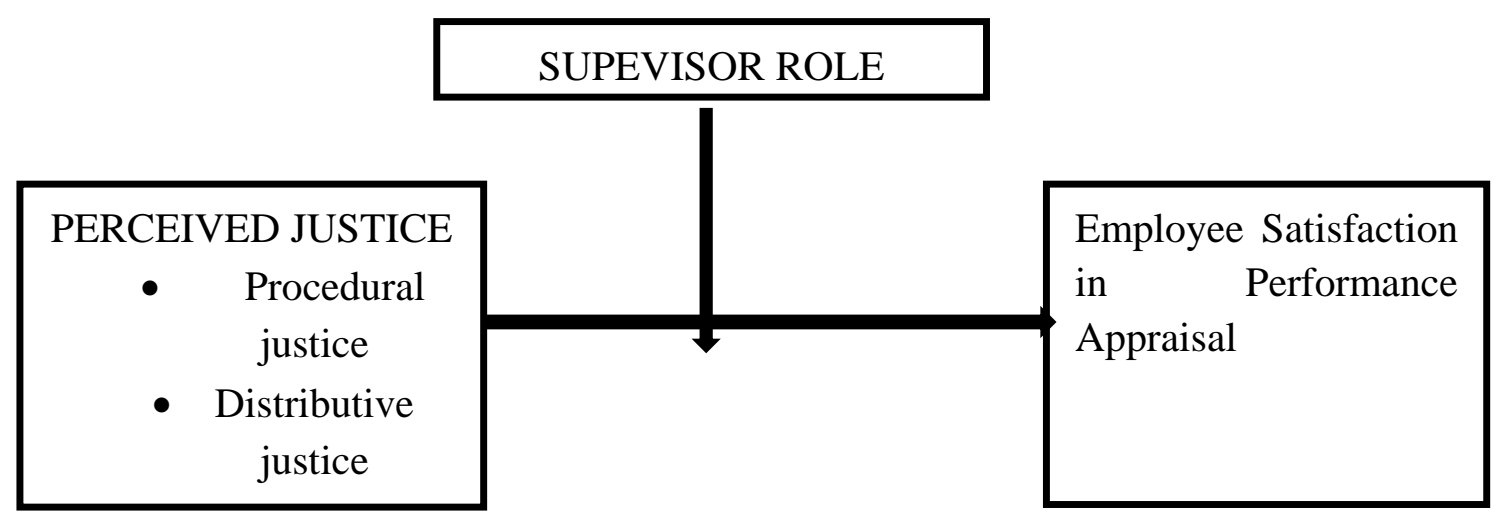

Figure 3.1. Research Framework

\section{Hypothesis}

H1: Perceived justice has a significant impact on employee satisfaction.

H2: Supervisor role has a moderating impact on the relationship of perceived justice and employee satisfaction.

H3: Procedural justice in performance appraisal has a significant impact on employee 
satisfaction.

H4: Distributive justice in performance appraisal has a significant impact on employee satisfaction

H5: There is a significant difference existed among the perception of employees of private and public sector regarding performance appraisal.

The review of previews studies regarding these concepts revealed that, perception of justice in performance appraisal is very necessary for its effective implementation and getting productive results. Further, investigation provides beneficial and valuable results to reader about the performance appraisal practices in private and public institutions of Pakistani Organizations.

\section{Research Methodology}

The research comprised extent of worker perceptions of the justice in process of performance appraisal founded on a hypothesized theoretical model of perceived justice in performance appraisal. Data for this study were collected from the Public and Private Banks and Airline sector of Pakistan.

Survey Questionnaire - The main aim of survey questionnaire is to explore the answers of the respondents as related to their perception about the Performance Appraisal System implemented by Public and Private institutions of Pakistan. Respondents of the investigation were from all departments of the organization and from all level such as employees and department heads.

\section{Population and Sample Description}

Non probability (convenient sampling) technique is used to collect the data. Banking and Airline sector is used to collect the required data. Banking and Airline sector is used to collect the required data. Response in equal proportion was gathered from each sector. Total 240 questionnaire was distributed, in which 200 returned completely, some were missing and some were misplaced by the respondents.

\section{Selection of Respondents}

Data were gathered from all positions in the each company the administrative, middle level employees, specialized, managerial and administrative workforce in different public and private institutions of Pakistan in 2016. All respondents answer the questions as ratee in the process of performance appraisal.

\section{Data Analysis and Discussion}

\subsection{Regression Analysis}

Regression Analysis for Procedural Justice and Distributive Justice as independent variable and Employee satisfaction as Dependent variable and Supervisor role as Moderator 
Table 4.1. Summary Table of Regression Analysis

\begin{tabular}{|c|c|c|c|c|c|c|}
\hline Models & $\mathrm{R}$ & square & $\mathrm{F}$ & Sig & Beta & Sig \\
\hline \multicolumn{7}{|l|}{ Model 1} \\
\hline $\begin{array}{l}\text { Employee } \\
\text { Satisfaction }\end{array}$ & $\begin{array}{l}\text { Procedural } \\
\text { Justice and } \\
\text { Distributive } \\
\text { Justice }\end{array}$ & .438 & 76.74 & .000 & $\begin{array}{l}.370 \\
.328\end{array}$ & .000 \\
\hline $\begin{array}{l}\text { Model } 2 \\
\text { Employee } \\
\text { Satisfaction }\end{array}$ & $\begin{array}{l}\text { Distributive } \\
\text { Justice }\end{array}$ & .388 & 125.286 & .000 & .623 & .000 \\
\hline $\begin{array}{l}\text { Model } 3 \\
\text { Employee } \\
\text { Satisfaction }\end{array}$ & $\begin{array}{l}\text { Procedural } \\
\text { Justice }\end{array}$ & .398 & 131.053 & .000 & .631 & .000 \\
\hline $\begin{array}{l}\text { Model } 4 \\
\text { (Moderation } \\
\text { Effect) } \\
\text { M_IV }\end{array}$ & $\begin{array}{l}\text { M_PJ } \\
\text { M_DJ }\end{array}$ & .397 & 64.96 & .000 & $\begin{array}{l}.340 \\
.304\end{array}$ & $\begin{array}{l}.000 \\
.016 \\
.032\end{array}$ \\
\hline
\end{tabular}

The model 1 summary shows that $27 \%$ variations are happening in employee satisfaction due to change in relationship of Procedural Justice and Distributive Justice which are dimensions of perceived justice of performance appraisal. The ANOVA table shows the overall significance of the model as the $\mathrm{P}$ value (.000<.05) which means that overall model is significant. So, H1 is accepted that Perceived Justice in performance appraisal has significant positive impact on the overall Employee Satisfaction. Further it is proved from ANOVA table that Procedural Justice and Distributive Justice are determinants of Perceived Justice.

The model 2 summary shows that $38 \%$ variations are happening in employee satisfaction due to change in Distributive Justice of performance appraisal. The ANOVA table shows the relationship of Distributive Justice and Employee Satisfaction is significant as the $\mathrm{P}$ value $(.000<.05)$ which means that overall model is significant. So, H4 is accepted that Perceived Distributive Justice in performance appraisal has significant positive impact on the overall Employee Satisfaction.

As shown by the Model Summary that value of R square has decreased from .438 to .397 and the ANOVA value is significant that $\mathrm{P}$ value is .000 which is less than .05 . Therefore, it is proved that supervisor role has no significant impact on the relationship of perceived justice in performance Appraisal and Employee Satisfaction. Hence, $\mathrm{H} 2$ rejected.

The model 3 summary shows that $39 \%$ variations are happening in employee satisfaction due 
to change in Procedural Justice of performance appraisal. The ANOVA table shows the relationship of procedural justice and employee satisfaction is significant as the $\mathrm{P}$ value $(.000<.05)$ which means that overall model is significant. So, H3 is accepted that Perceived Procedural Justice in performance appraisal has significant positive impact on the overall Employee Satisfaction.

\subsection{Independent Sample T-Test}

Table 4.2. T Test

\section{T-TEST}

\begin{tabular}{l|l|l|l|l}
\hline \multirow{2}{*}{$\begin{array}{l}\text { Organizational } \\
\text { Performance }\end{array}$} & $\begin{array}{l}\text { Organizational } \\
\text { Type }\end{array}$ & $\mathrm{N}$ & Mean & Sig. (2-tailed) \\
\cline { 2 - 5 } & Public & 100 & 3.3140 & .000 \\
\cline { 2 - 5 } & Private & 100 & 3.6180 & .000 \\
\hline
\end{tabular}

Table of Independent Sample test proved that under 95\% confidence interval the measurement of difference of results among Public and Private institution is valid, because the significant value is .000 which is less than .05 . It also shows the minimal difference of mean in both divisions of organization type. The mean difference of Procedural Justice between Public and Private Institution -.47500, for Distributive Justice the difference is -.68200 , for Supervisor role is -.48200 and for Employee satisfaction the mean difference is -.30400. so, H5 rejected. Therefore, overall result show that the difference in perception of justice about performance appraisal in employees of Public and Private sector is very less. The negative sign shows that most of the employees are less satisfied with the existing system of performance appraisal.

\section{Findings and Conclusion}

The overall, study is linked to the perception of the workers of different Public and Private institutions of Pakistan, concerning the drives of their (PAS) Performance Appraisal. The results on the perception of workers will need a greater check of its efficiency and for a conceivable adjustments or improvement of the existing appraisal system.

Hypothesis 1: Perceived justice has a significant impact on employee satisfaction.

The overall results of Regression Analysis is significant and support this hypothesis, that most of the employees feel that perception about perceived justice in the process of performance appraisal is significantly related with employee satisfaction. This result is also supported by several preview studies (Rownald, C, \& Hall, R. 2013; Erdogan, Kraimer \& Liden, 2001; Lira M, 2015) about the relation of perception of justice and employee level of satisfaction. 
Hypothesis 2: Supervisor role has a moderating impact on the relationship of perceived justice and employee satisfaction.

This hypotheses is rejected, the results not support the supervisor role as moderator, similar to the preview study in which researcher F. Young, S., \& A. Steelman, L. (2014) find that the supervisor role is more significant as mediator not as moderator.

Hypothesis 3: Procedural justice in performance appraisal has a significant impact on employee satisfaction.

The third hypothesis is accepted the procedural justice has a significant relationship with employee satisfaction as dependent variable. Several previews studies also support this results because the justice in procedure mostly led to the justice in final decision making which directly increased the satisfaction level of employees.

Hypothesis 4: Distributive justice in performance appraisal has a significant impact on employee satisfaction.

The fourth hypothesis is also accepted, the distributive justice in performance appraisal also increased the employee's satisfaction.

Hypothesis 5: There is a significant difference existed among the perception of employees of private and public sector regarding performance appraisal.

This hypothesis is rejected because result of t-test shows minimal difference among the data of private and public sector. Almost all respondents of both sectors show similar response and are equally dissatisfied with appraisal procedure of their organizations.

The results also similar with the preview study of Lira. M, (2015) about the employees perception of justice in performance appraisal in government sector of Portugal, which shows that there is a great need for improvement in appraisal procedure of public sector. This results of this study provide additional information by comparing the data among public and private sector of Pakistan. The results shows minimal difference among the procedure of performance appraisal in both sectors of Pakistan. The results of the $4^{\text {th }}$ section of the questionnaire shows that employees of both sectors are less satisfied with the appraisal system of their institutions. So, there is a great need for improvement to increase the level of satisfaction of employees to increase their commitment with the organization.

\section{Recommendations}

Based on the results of this study the subsequent recommendations for the enhancement of the present PAS of the Public and Private institutions of Pakistan are believed suitable by the researcher: There should be proper feedback system is implemented in each organization as the behavior of employees shows that due to lack of proper feedback system more flaws are existed in PAS. Proper Training also useful for the supervisors for greater level performance management methods that would prepare them to develop and increase the effectiveness of PAS which in return enhance employee's performance. There should be clear criterions set for appraising the employees and every employee must be understand those standards of 
evaluation.

Supervisors should remove the general assessment errors for example leniency mistakes. Adjustment of some guiding principle on Performance Appraisal System concerning identification of standard on responsibilities and accountabilities or the job tasks of workers. Higher level of employee involvement is very necessary for generating perception of justice in the minds of employees. So Employees and supervisors should properly communicate and collaborate with each other to improve the PAS and achieve the organizational goals. Similarly, when employees are involved in any procedure, they show more participation and interest, and greater involvement of employees decrease the tension and conflicts while increase the cooperation among employees and managers.

\section{Limitation of the Research}

To carry out the future research linked to this topic, in this study the researcher used quantitative techniques alone to analyze the data; this was selected as it suitable the goals and aims of the research. In reflection, if the investigator was to work on the same topic or any relevant topic again, it is better to use both quantitative and qualitative methods of investigation. Merging both kinds of research approaches is recognized to give a more smoothed interpretation and can appear at the study goals more systematically.

\section{Theoretical and Managerial Implications}

The study results on the procedures connecting employee's perception of justice in performance appraisal process make numerous important contributions to the literature and theory about the PAS. The results of the present study strengthen the generalization of the findings of previews researcher and also provide some Gap for future researchers.

The findings of this study also have some important practical implications. The objectives of performance appraisal and their diverse influence on workers' perceived justice is necessary for increasing the performance of employees through enhancing their level of satisfaction. These results are very beneficial for the HR departments of the target organization, the managers of those organizations can improve their PAS through reading the findings of this study, which provide them the thoughts and perceptions of their employees. It will give them a way to improve their overall PAS and enhance employee level of satisfaction.

\section{References}

Abu-Doleh, J., \& Weir, D. (2007). Dimensions of performance appraisal systems in Jordanian private and public organizations. The International Journal of Human Resource Management, 18(1), 75-84. https://doi.org/10.1080/09585190601068334

Ahmed, I., Ramzan, M., Mohammad, S. K., \& Islam, T. (2011). Relationship between perceived fairness in performance appraisal and OCB; mediating role of organizational commitment. International journal of academic research, 3(5), 15-20.

Boachie-Mensah, F. O., \& Seidu, P. (2012). 'Employees' Perception of Performance Appraisal System: A Case Study'. International Journal of Business \& Management, 7(2), 
73-88.

Cohen-Cherish, Y., \& Spector, P. E. (2001). The role of justice in organization: a met analysis. Organizational Behavior and Human Decision Process, 86(2), 278-321. https://doi.org/10.1006/obhd.2001.2958

Cole, N., \& Flint, D. (2004). Perceptions of distributive and procedural justice in employee benefits: flexible versus traditional benefit plans. Journal of Managerial Psychology, 19(1), 19-40. https://doi.org/10.1108/02683940410520646

Cook, J., \& Crossman, A. (2004). Satisfaction with performance appraisal systems. Journal of Managerial Psychology, 19(5), 526-541. https://doi.org/10.1108/02683940410543605

DeNisi, A. (ed.) (2000). Performance Appraisal and Performance Management: A Multilevel Analysis. San Francisco, CA: Jossey-Bass.

Desler, G. (2008). Human Resource Management (11th ed.). Upper Saddle River, New Jersey, USA: Pearson .

Erdogan, B. (2002). Antecedents and consequences of justice perceptions in performance appraisals. Human Resource Management Review, 12(4), 555-578. https://doi.org/10.1016/S1053-4822(02)00070-0

F. Young, S., \& A. Steelman, L. (2014). The role of feedback in supervisor and workgroup identification. Personnel Review, 43(2), 228-245. https://doi.org/10.1108/PR-01-2013-0006

Fletcher, C. (2001). Performance appraisal and management: The developing research agenda. Journal of Occupational and Organizational Psychology, 74(4), 473-487. https://doi.org/10.1348/096317901167488

Gomez-Mejia, L. R., Balkin, D. B., \& Cardy, R. L. (2010). Managing Human Resources (6th ed.). Boston, USA: Prentice Hall.

Greenberg, J. (1986). Determinants of perceived fairness of performance evaluations. Journal of applied psychology, 71(2), 340. https://doi.org/10.1037/0021-9010.71.2.340

Gupta, V., \& Kumar, S. (2012). Impact of performance appraisal justice on employee engagement: a study of Indian professionals. Employee Relations, 35(1), 61-78. https://doi.org/10.1108/01425451311279410

Ikemefuna, C. O., \& Chidi, C. O. (2012). Workers' Perception of Performance Appraisal in Selected Public and Private Organizations in Lagos Metropolis, Nigeria. International Journal of Human Resource Studies, 2(3), 80. https://doi.org/10.5296/ijhrs.v2i3.2221

Ikramullah, M. B. S. et al. (2012). Purposes of Performance Appraisal System: A Perceptual Study of Civil Servants in District Dera Ismail Khan Pakistan. International Journal of Business and Management, 7(3), 142-151. https://doi.org/10.5539/ijbm.v7n3p142

Jackson, S., \& Schuler, R. S. (2003).Managing human resources through strategic partnership Eight Edition. Ohio, USA: Thomson South-Western. 
Jawahar, I. (2007). The Influence of Perceptions of Fairness on Performance Appraisal Reactions. J Labor Res, 28(4), 735-754. https://doi.org/10.1007/s12122-007-9014-1

Kuvaas, B. (2011). The interactive role of performance appraisal reactions and regular feedback. Journal of Managerial Psychology, 26(2), 123-137. https://doi.org/10.1108/02683941111102164

Lira, M. (2015). Satisfaction with a performance appraisal system in the Portuguese public sector: The importance of perceptions of justice and accuracy. Tékhne, 12, 30-37. https://doi.org/10.1016/j.tekhne.2015.01.005

Mondy, R. W., Noe, R., \& Premeaux, S. R. (2002). Type Z organization: Stability in the midst of mobility. Human Resource Management, 308.

Nair, M. S., \& Salleh, R. (2015). Linking Performance Appraisal Justice, Trust, and Employee Engagement: A Conceptual Framework. Procedia-Social and Behavioral Sciences, 211, 1155-1162. https://doi.org/10.1016/j.sbspro.2015.11.154

Naji, A., Mansour, J., \& Leclerc, A. (2015). Performance Appraisal System and Employee Satisfaction: The role of trust towards supervisors"Journal of Human Resources Management and Labor Studies June 2015.

Richard, J., Eberlin, B., \& Charles, T. (2008). Making just decisions: organizational justice, decision making, and leadership, Management Decision, 46(2), 310 - 329. https://doi.org/10.1108/00251740810854177

Robbins, S. P. (2005). Organizational behavior (11th end). Prentice Hall International, New Jersey, NJ.

Rowland, C. A., \& Hall, R. D. (2012). Organizational justice and performance: is appraisal fair?. EuroMed Journal of Business, 7(3), 280-293. https://doi.org/10.1108/14502191211265334

Rownald, C., \& Hall, R. (2013). Perceived unfairness in appraisal: engagement and sustainable organizational performance, EuroMed Journal of Business, 8(3), 195 - 208. https://doi.org/10.1108/EMJB-06-2013-0034

Tatum, B. C., Bradberry, T., Eberlin, R., \& Kottraba, C. (2002). Organizational justice and performance as measured by 360-degree feedback. In 18th Annual Convention of the Associatioin for Psychological Science.

Vance, R. J. (2006). Employee Engagement and Commitment: A Guide to Understanding. Measuring and Increasing Engagement in Your Organization. 1st Edn., SHRM Foundation, Alexandria, 45.

Werner, J. M., \& Bolino, M. C. (1997). Explaining US Courts of Appeals decisions involving performance appraisal: accuracy, fairness, and validation, Personnel Psychology, 50(1), 1-24. https://doi.org/10.1111/j.1744-6570.1997.tb00898.x

Wilson, P. J., \& Western, S. (2000). Performance appraisal: an obstacle to training and 
development?. Journal of European Industrial Training, 24(7), 384-91. https://doi.org/10.1108/03090590010377754

Annexes

Questionnaire

Perception of Justice in Performance Appraisal; a Comparative Study of Public and Private Institutions of Pakistan

Gender $\quad$ Male $\quad$ Female

Employment Duration 1-3 years 4-6years 7-10years above 10yrs

Level of Education under Graduate Graduate Post Graduate

Organization Name

The questions in this section investigate your general impressions of the performance appraisal practices in your organization.

Please indicate the extent you agree or disagree with the following statements.

PROCEDURAL JUSTICE IN PERFORMANCE APPRAISAL

1. The organization's performance appraisal policy and procedures are impartial.

Strongly disagree Disagree Neutral Agree Strongly Agree

2. Assessments are not influenced by the person's status.

Strongly disagree Disagree Neutral Agree Strongly Agree

3. Procedures ensure that assessments are based on accurate information.

Strongly disagree Disagree Neutral Agree Strongly Agree

4. People get the ratings they deserve even if it might upset them.

Strongly disagree Disagree Neutral Agree Strongly Agree

5. The organization's policy and procedures ensure supervisors and rating panels are familiar with the assessment procedures.

Strongly disagree Disagree Neutral Agree Strongly Agree

6. The planning process is useful

Strongly disagree Disagree Neutral Agree Strongly Agree

DISTRIBUTIVE JUSTICE IN PERFORMANCE APPRAISAL

7. Assessments are not based on a person's popularity.

Strongly disagree Disagree Neutral Agree Strongly Agree 
8. The appraisal system in general is satisfactory.

Strongly disagree Disagree Neutral Agree Strongly Agree

9. The year-end ratings are satisfactory

Strongly disagree Disagree Neutral Agree Strongly Agree

10. The performance bonus I received is according to my performance.'

Strongly disagree Disagree Neutral Agree Strongly Agree

\section{SUPERVISOR ROLE}

11. Leaders in my organization implement performance appraisal practices in ways that are fair.

Strongly disagree Disagree Neutral Agree Strongly Agree

12. I felt comfortable discussing my performance with my supervisor.

Strongly disagree Disagree Neutral Agree Strongly Agree

13. The system requires my supervisor or rating panel is to seek information from reliable and relevant sources.

Strongly disagree Disagree Neutral Agree Strongly Agree

14. My supervisor was straightforward with me

Strongly disagree Disagree Neutral Agree Strongly Agree

15. My supervisor did not try to deceive me.

Strongly disagree Disagree Neutral Agree Strongly Agree

16. I have filed a formal complaint about my supervisor.

Strongly disagree Disagree Neutral Agree Strongly Agree

\section{EMPLOYEES SATISFACTION}

Please indicate the extent that you are agree or disagree with each of the following statements.

17. During the last rating period I believe my contributions to the organization have been satisfied

Strongly disagree Disagree Neutral Agree Strongly Agree

18. I was given sufficient opportunity to respond to my supervisor's assessment.

Strongly disagree Disagree Neutral Agree Strongly Agree

19. I complete tasks successfully. 
Strongly disagree Disagree Neutral Agree Strongly Agree

20. I have good relationships with my supervisor.

Strongly disagree Disagree Neutral Agree Strongly Agree

21. I have complained to my family and friends about the performance appraisal practices

Strongly disagree Disagree Neutral Agree Strongly Agree

22. I have made positive statements about the system to others.

Strongly disagree Disagree Neutral Agree Strongly Agree

23. I have made positive statements about my supervisor to others.

Strongly disagree Disagree Neutral Agree Strongly Agree

24. I am proud to tell others that I am part of my organization.

Strongly disagree Disagree Neutral Agree Strongly Agree

25. I am glad I chose this organization to work for over others I was considering at the time I joined.

Strongly disagree Disagree Neutral Agree Strongly Agree

26. I am willing to put in a great deal of effort beyond that normally expected in order to help my organization be successful.

Strongly disagree Disagree Neutral Agree Strongly Agree

REFERENCE (Thurston Jr, P. W., \& McNall, L. (2010). Justice perceptions of performance appraisal practices. Journal of Managerial Psychology, 25(3), 201-228.)

\section{Copyright Disclaimer}

Copyright for this article is retained by the author(s), with first publication rights granted to the journal.

This is an open-access article distributed under the terms and conditions of the Creative Commons Attribution license (http://creativecommons.org/licenses/by/4.0/). 